\title{
Transfer of the mlo resistance gene into to the genome of winter barley
}

\section{Wprowadzenie genu mlo do genomu jęczmienia ozimego}

\author{
Jerzy H. Czembor ${ }^{1 *}$, Paweł Cz. Czembor ${ }^{2}$, Olga Doraczyńska ${ }^{1}$, \\ Aleksandra Pietrusińska ${ }^{1}$, Magdalena Radecka-Janusik ${ }^{2}$
}

\section{Summary}

The aim of the study was to transfer mlo gene, which determines very effective resistance to powdery mildew (Blumeria graminis DC. f. sp. hordei) from spring barley to winter forms and to determine agronomic value of selected breeding lines under field conditions. The spring barley cultivar Danuta was used as a donor of mlo gene. Mlo gene was introduced into genome of the two multi-row winter cultivars Carola and Bażant, with good agronomic value but susceptible to powdery mildew. Powdery mildew resistance was evaluated under field conditions and natural infection in several homogenous lines with Mlo resistance type, which were selected from generated $\mathrm{F}_{1}, \mathrm{~F}_{1} \mathrm{BC}_{1}, \mathrm{~F}_{2} \mathrm{BC}_{1}$ populations. The homogenous line $\mathrm{BKH} 5735$ resistance to $B$. graminis $\mathrm{f}$. $\mathrm{sp}$. hordei determined by mlo gene was selected as a result of evaluations under controlled conditions, natural infection and using molecular markers. This line showed good economic value comparable to the control varieties and it may be concluded that the line BKH 5735 has Mlo resistance and provides high-yielding.

Key words: Blumeria graminis f. sp. hordei; mlo gene; winter barley; resistance

\section{Streszczenie}

Celem podjętych badań było przeniesienie z form jarych do ozimych genu mlo warunkującego wysoce efektywną odporność na mączniaka prawdziwego zbóż i traw (Blumeria graminis DC. f. sp. hordei). Do wyprowadzenia linii jęczmienia ozimego, wielorzędowego o odporności na mączniaka prawdziwego wykorzystano jako dawcę genu mlo odmianę jęczmienia jarego Danuta. Jako biorców genu mlo użyto dwie odmiany wielorzędowe ozime: Carola i Bażant o dobrej wartości cech gospodarczych, lecz podatnych na mączniaka. Wytworzono populacje mieszańcowe: $F_{1}, F_{1} B_{1}, F_{2} B C_{1}$ i po wyselekcjonowaniu linii ozimych $i$ homozygotycznych pod względem odporności na mączniaka typu Mlo oceniono ich wartość w doświadczeniach w warunkach naturalnej infekcji. W wyniku przeprowadzonych badań uzyskano linię BKH 5735 odporną na B. gramins f. sp. hordei uwarunkowaną genem mlo. Linia ta, w warunkach naturalnej infekcji doświadczeń polowych charakteryzowała się porównywalną oceną innych cech wartości gospodarczych do odmian wzorcowych.

Słowa kluczowe: Blumeria graminis f. sp. hordei; gen mlo; jęczmień ozimy; odporność

\footnotetext{
Instytut Hodowli i Aklimatyzacji Roślin - Państwowy Instytut Badawczy

${ }^{1}$ Krajowe Centrum Roślinnych Zasobów Genowych

${ }^{2}$ Zakład Genetyki i Hodowli Roślin

Radzików, 05-870 Błonie

*corresponding author: j.h.czembor@ihar.edu.pl
} 


\section{Wstęp / Introduction}

Mączniak prawdziwy zbóż i traw [Blumeria graminis DC. f. sp. hordei (Marchal)] występujący na jęczmieniu to jedna $\mathrm{z}$ ważniejszych chorób $\mathrm{w}$ rejonach świata o klimacie morskim, w tym, w Polsce (Rasmusson 1985). Występuje z różnym nasileniem na terenie całego kraju powodując straty w plonach (Gacek i wsp. 1996). W warunkach sprzyjających rozwojowi grzyba straty w plonie ziarna mogą sięgać 25\%, natomiast przeciętnie wynoszą około 10\% (Kozdój i wsp. 2009). Silniejsze wystąpienie mączniaka na jęczmieniu browarnym prowadzi do pogorszenia wartości technologicznej ziarna, jako surowca dla przemysłu piwowarskiego, głównie $\mathrm{z}$ powodu podwyższenia zawartości białka (Pecio i Bichoński 2003). Straty w plonie ziarna można ograniczyć przez stosowanie odpowiednich fungicydów, uprawę odmian odpornych oraz wykorzystanie naturalnych mechanizmów współzależności roślin między sobą i środowiskiem (Czembor i Gacek 1990; Gacek 1990; Nieróbca i wsp. 2003). Odporność uprawianych odmian na patogeny i możliwie duże jej zróżnicowanie pod względem uwarunkowań genetycznych jest jednym z ważniejszych elementów nowoczesnej proekologicznej produkcji roślinnej.

W ostatnich dziesięcioleciach, hodowcy jęczmienia w całej Europie, w swoich programach hodowlanych powszechnie wykorzystywali genotypy, których odporność na mączniaka prawdziwego uwarunkowana była genami, takimi jak: Mla6, Mla 7, Mla9, Mla12 i Mla13 w locus Mla oraz geny: Mlk, Mlg, Ml(La), Mlh i Mlra (Dreiseitl 1991b, 2011 b, c, 2012, 2014a, b; Czembor i Czembor 1998, 1999, 2001; Dreiseitl i Platz 2012). Dla właściwego doboru źródeł odporności w hodowli nowych odmian jęczmienia odpornych na mączniaka potrzebna jest wiedza o strukturze frekwencji genów wirulencji w populacji $B$. graminis f. sp. hordei. Jest to patogen, zdolny do wytwarzania ras o nowych zdolnościach chorobotwórczych, które rozprzestrzeniają się na duże odległości w krótkim czasie. Jeżeli odmiana z określonym genem odporności uprawiana była na dużych powierzchniach to już po kilku latach, gen ten stawał się nieefektywny. Badania, które mają na celu monitorowanie genów wirulencji tego patogena prowadzone są na szeroką skalę zarówno w Polsce (Czembor i Czembor 2001, 2004a, b, 2005; Czembor 2003, 2004; Gacek i wsp. 2004), jak i za granica (Dreiseitl 1991a, 1997, 1998, 2004, 2008, 2011a, d, 2014a; Dreiseitl i Schwarzbach 1994; Limpert i wsp. 1999; Hovmøller i wsp. 2000; Dreiseitl i Kosman 2013). Na podstawie tych badań hodowcy uzyskują informacje, które genotypy wyłączyć z programów hodowlanych, ponieważ nie będą warunkowały odporności na mączniaka prawdziwego. Wyjątkiem jest recesywny gen mlo (Czembor i Czembor 2003). Początkowo, negatywne efekty plejotropowe ograniczyły jego wykorzystanie w hodowli jęczmienia (Bjørnstad i Aastveit 1990). Jednak dalsze prace hodowlane pozwoliły na ich wyeliminowanie i obecnie wykorzystanie tego typu odporności stało się szczególnie powszechne w jęczmieniu jarym (Szarzyńska 2015). Nadal, pomimo tego, że warunkuje on odporność odmian uprawianych na dużych powierzchniach, nie stwierdzono występowania wirulencji $\mathrm{w}$ populacji $B$. graminis f. sp. hordei $\mathrm{w}$ stosunku do tego genu. Opisano ponad 30 alleli genu mlo, a w hodowli wykorzystuje się głównie Mlo9, Mlo5 i Mlo11 (Hovmøller i wsp. 2000).

$\mathrm{W}$ dostępnej literaturze brak doniesień o odmianach jęczmienia ozimego $\mathrm{z}$ genem mlo dobrze przystosowanych do polskich warunków środowiska (Czembor i wsp. 2013; Dreiseitl 2013). Nie ma takich odmian również w doborze odmian jęczmienia ozimego w Niemczech, Wielkiej Brytanii, Danii i Czechach (Listy opisowe wymienionych krajów za 2012 lub 2013 rok).

Celem podjętych badań było przeniesienie $\mathrm{z}$ form jarych do ozimych genu mlo warunkującego wysoce efektywną odporność na mączniaka (B. graminis f. sp. hordei) i określenie interakcji genu mlo w genomie form ozimych w warunkach naturalnej infekcji.

\section{Materiały i metody / Materials and methods}

Do wyprowadzenia linii jęczmienia ozimego, wielorzędowego o odporności na mączniaka prawdziwego ( $B$. graminis f. sp. hordei) wykorzystano jako dawcę genu mlo niemiecką 2-rzędową odmianę jęczmienia jarego Danuta, której odporność na mączniaka typu Mlo uwarunkowana jest recesywnym genem mlo $_{11}$ (Schwarzbach 2008). Jako biorców genu mlo użyto dwóch odmian wielorzędowych ozimych: Carola i Bażant o dobrej wartości cech gospodarczych, lecz podatnych na mączniaka (Anonymous 2004).

W warunkach kontrolowanych szklarni i fitotronu oceniono odporność wytworzonych populacji mieszańcowych $\mathrm{F}_{1}, \mathrm{~F}_{1} \mathrm{BC}_{1}, \mathrm{~F}_{2} \mathrm{BC}_{1}$ na zakażenie izolatem 63 B. graminis f. sp. hordei, wirulentnym w stosunku do rodziców ozimych, a awirulentnym do odmiany Danuta. $\mathrm{Na}$ potomstwie roślin $\mathrm{F}_{2} \mathrm{BC}_{1}$, metodą rezerw - rozmnożenie roślin bez jarowizacji w warunkach wysokich temperatur $-19^{\circ} \mathrm{C}$ noc 6 godzin, $25^{\circ} \mathrm{C}$ dzień 18 godzin, określono ich fenotyp, forma jara versus ozima.

$\mathrm{W}$ celu potwierdzenia obecności genu mlo w roślinach pokolenia $\mathrm{F}_{1} \mathrm{BC}_{1}$ stosowano również dwa molekularne markery mikrosatelitarne HvMLOH1A i HvMLO3 amplifikowane $\mathrm{w}$ reakcji PCR (polymerase chain reaction), które są sprzężone z locus Mlo (Ramsay i wsp. 2000; Karakousis i wsp. 2003). Na potrzeby analiz molekularnych izolowano DNA (deoxyribonucleic acid) z kilkutygodniowych pojedynczych roślin reprezentujących 106 linii $\mathrm{F}_{1} \mathrm{BC}_{1}$, które utrzymywano $\mathrm{w}$ warunkach kontrolowanych komory fitotronowej ( 16 godzin światła/ $22^{\circ} \mathrm{C}$ oraz 8 godzin ciemności $\left./ 18^{\circ} \mathrm{C}\right)$. Do amplifikacji w reakcji PCR markera HvMLOH1A wykorzystywano DNA otrzymane przy użyciu zestawu DNeasy Plant Mini Kit 250 (QIAGEN, Syngen Biotech, Polska) zgodnie z zaleceniami producenta. Natomiast, do amplifikacji w reakcji PCR markera HvMLO3 zastosowano DNA otrzymane za pomocą buforu TPS (Higgins i wsp. 2000). Mieszanina reakcyjna o objętości $8 \mu \mathrm{l}$ zawierała następujące komponenty: $3 \mu 1$ DNA (około $100 \mathrm{ng}$ ), $1 \times$ bufor (Fermentas, Thermo Fisher Scientific, Waltham, USA), 2,5 $\mathrm{mM}$ $\mathrm{MgCl}_{2}, \quad 0,2 \mathrm{mM}$ dNTPs, 0,5 $\mu \mathrm{M}$ każdego startera i 1 jednostka polimerazy Taq (Fermentas). W przypadku markera HvMLOH1A użyto pary starterów 5'-CCTCCCC 
TCTGATATGATAA-3' i 5'-GTACAGACGGTTTAATT GTCC-3', natomiast dla HvMLO3 użyto 5'-CTT CCATGTCACCTACAGC-3' i 5'-CGAACTGGTATTCC AAGG-3'. Jeden starter $\mathrm{z}$ każdej pary starterów był dodatkowo znakowany na końcu 5' barwnikiem fluorescencyjnym TET w formie amidofosforynu (Applied Biosysytems, Foster City, Stany Zjednoczone). Reakcję PCR prowadzono w termocyklerze Mastercycler ep (Eppendorf Poland Sp. z o.o., Warszawa, Polska) według programu: $94^{\circ} \mathrm{C} / 3$ min. wstępna denaturacja, 10 cykli składających się z etapów $94^{\circ} \mathrm{C} / 30 \mathrm{~s}, 55^{\circ} \mathrm{C} / 30 \mathrm{~s} \mathrm{i} 72^{\circ} \mathrm{C} / 1 \mathrm{~min}$. oraz 30 cykli przy obniżonej temperaturze denaturacji do $90^{\circ} \mathrm{C}$, reakcja kończyła się inkubacją $72^{\circ} \mathrm{C} / 5 \mathrm{~min}$.

Rozdział i analizę znakowanych produktów PCR prowadzono przy użyciu analizatora DNA ABI377XL (Applied Biosystems) wspomaganego oprogramowaniem GeneScan 3.1 (Applied Biosystems), stosując 4,5\% denaturujący żel poliakrylamidowy (Long Ranger, Cambrex Bio Science, USA). Do nanoszenia mieszaniny poreakcyjnej na żel poliakrylamidowy stosowano grzebienie membranowe (100 zębów) zgodnie $\mathrm{Z}$ zaleceniem producenta (Web Scientific Ltd., Wielka Brytania). Występowanie produktów PCR o długości 176 pz (par zasad) dla markera HvMLO3 i 230 pz dla HvMLOH1A świadczyło o obecności genu mlo $\mathrm{w}$ danej linii.

Rozmnożenia, reselekcję na wartość cech gospodarczych oraz doświadczenia pojedyncze prowadzono w szkółce polowej Instytutu Hodowli i Aklimatyzacji Roślin - Państwowego Instytutu Badawczego w Radzikowie na mikropoletkach. Jednoczynnikowe doświadczenie „MLO” z 60 rodami jęczmienia ozimego wielorzędowego przeprowadzono w miejscowości Bąków, w sezonie 2008/2009, w celu oznaczenia poziomu plonowania i wyliczenia odchyleń plonowania badanych obiektów od odmian wzorcowych. Zastosowano metodę 1-powtórzeniową z 2 wzorcami: Maybrit i Nickela, wysianymi systematycznie na przemian co dziesiąte poletko. W okresie wegetacji wykonano obserwacje przezimowania, podatności na wyleganie i porażenia chorobami (skala 1-9), po zbiorach oznaczono plon ziarna $\mathrm{z}$ poletka (przy 15\% wilgotności) przeliczony na dt/ha (tab. 1).

W sezonie 2009/2010 przeprowadzono serię jednoczynnikowych doświadczeń „MLO” z 33 rodami jęczmienia wielorzędowego oraz 3 odmianami wzorcowymi: Maybrit, Nickela i Rosita w 3 miejscowościach: Bąków, Szelejewo i Wiatrowo. Zastosowano metodę bloków niekompletnych. Obiekty wysiano na poletkach o powierzchni $10 \mathrm{~m}^{2}$ w 3 powtórzeniach. Rozmieszczenie obiektów w miejscowościach było stałe. Po zbiorach ocenie poddano plon ziarna $\mathrm{z}$ poletka (przy wilgotności $15 \%$ ). Na podstawie wyników plonowania wykonano analizę wariancji dla plonu. Testem $F$ badano istotność średnich kwadratów odchyleń dla obiektów względem średniego kwadratu odchyleń dla błędu doświadczalnego. Zestawiono plony obiektów w miejscowościach i średnie plonów (w dt/ha) uszeregowane malejąco, średnie generalne wartości dla miejscowości i obiektów wzorcowych, współczynniki zmienności dla błędu, współczynniki zgodności plonu, ocenę NIR (0,05) oraz NIRP (\%) (tab. 2).

Do oceny porażenia przez choroby $w$ warunkach naturalnej infekcji i wylegania zastosowano zalecaną przez
Centralny Ośrodek Badania Odmian Roślin Uprawnych (COBORU) skalę 1-9, gdzie 1 - oznacza porażenie liści do flagowego włącznie, a 9 - brak objawów. W ocenie wylegania: 1 - oznacza całkowite wylegnięcie łanu, a 9 - brak wylegania. Do oceny reakcji roślin w stadium siewki, w warunkach kontrolowanych na zakażenie izolatem 63 B. graminis f. sp. hordei stosowano pięciostopniową skalę Mainsa i Dietza (1-4, gdzie 0 - brak widocznych objawów porażenia; 1 - niewielkie nekrozy; 2 - nekrozy powiększają się, skąpe zarodnikowanie; 3 chlorozy, grzybnia rozwinięta, lecz słabo zarodnikująca; 4 - dobrze rozwinięta i zarodnikująca grzybnia). Skala ta została uzupełniona o dodatkowy szósty stopień $0 / 4$ charakteryzujący reakcję odmian $\mathrm{z}$ genem mlo (Czembor i Czembor 2001).

\section{Wyniki i dyskusja / Results and discussion}

Badania, których celem było przeniesienie $\mathrm{z}$ form jarych do ozimych genu mlo warunkującego wysoce efektywną odporność na mączniaka (B. graminis f. sp. hordei) i określenie interakcji genu mlo w genomie form ozimych w warunkach naturalnej infekcji, prowadzono metodami tradycyjnymi, w oparciu o wyniki testów fitopatologicznych, jak i metodami molekularnymi, co zwiększyło skuteczność trafnego wyboru homozygotycznych roślin o odporności typu Mlo. Wykonano krzyżowania: proste odmian Carola $\times$ Danuta oraz wypierające $\mathrm{z}$ odmianą Bażant $\mathrm{w}$ warunkach fitotronowych i szklarniowych w ro$\mathrm{ku}$ 2005. Uzyskane populacje mieszańcowe $\mathrm{F}_{1} \mathrm{BC}_{1}$ poddano ocenie fenotypowej pod względem reakcji na zakażenie izolatem $B$. graminis f. sp. hordei wirulentnym w stosunku do odmian: Carola i Maybrit oraz molekularnej na obecność genu mlo pochodzącego z odmiany Danuta. Do analiz molekularnych wybrano 106 roślin pokolenia $\mathrm{F}_{1} \mathrm{BC}_{1}$, które $\mathrm{w}$ testach fitopatologicznych wykazywały reakcję odporności świadczącą o obecności genu mlo. Spośród tych roślin, 96 wykazywało jednocześnie obecność dwóch markerów związanych z występowaniem genu mlo. Analizy molekularne mające na celu wykazanie obecności genu mlo prowadzono z wykorzystaniem dwóch markerów HvMLOH1A oraz HvMLO3. Następnie wyodrębniono 21 roślin homozygotycznych i 25 heterozygotycznych dla genu mlo. Wybrane rośliny z genem $m l o$ po jarowizacji rozmnożono $\mathrm{w}$ fitotronie. Uzyskane populacje mieszańcowe $\mathrm{F}_{2} \mathrm{BC}_{1}$ metodą rezerw podano selekcji na wyróżnienie form ozimych. Potomstwa roślin o fenotypie jarych usunięto $\mathrm{z}$ dalszych prac. Po zjarowizowaniu reszt pojedynkowych roślin fenotypowo ozimych, wiosną 2006 roku wysadzono je w szkółce polowej. Na rozmnażanych liniach przeprowadzono ocenę wizualną pod względem cech wartości gospodarczej w porównaniu do odmian wzorcowych: wielorzędowej Rosita i dwurzędowej Nickela. $Z$ dalszych badań usunięto przede wszystkim linie $\mathrm{z}$ typowymi objawami plamistości plejotropowego efektu obecności genu mlo i wydzielono dwie grupy linii: grupę 2-rzędowych i 6-rzędowych, każda licząca odpowiednio po 20 roślin.

Jesienią 2006 roku w szkółce polowej wysiano na mikropoletkach, w siewie punktowym, do oceny wartości 
gospodarczej w naturalnych warunkach, 650 linii z odmianami wzorcowymi co dziesiąte poletko: odmiany Carola i Nickela.

W sezonie wegetacyjnym 2007 roku spośród 650 linii po ocenie do reselekcji wybrano 40 linii odpornych na mączniaka i o korzystnych innych cechach wartości gospodarczej. Z każdej linii zebrano po 20 roślin jako sublinie do rozmnożenia i oceny w sezonie $2007 / 2008$.

W szkółce polowej, w sezonie 2007/2008 wysiano 400 sublinii na 2-rządkowych mikropoletkach. Na wydzielonej próbie 20-25 nasion z każdej sublinii w fazie siewki przeprowadzono ocenę reakcji na zakażenie izolatem
63 B. graminis f. sp. hordei. Wśród ocenianych 400 sublinii, 319 charakteryzowało się homozygotyczną odpornością typu Mlo. W 99,4\% ocenianych linii potwierdzono związek specyficznych markerów z genem mlo. Uzyskane wyniki wykorzystano w ocenie sublinii w szkółce polowej w roku 2008. Po ocenie wizualnej potencjału wartości cech gospodarczych do dalszych badań wybrano 59 linii.

Z wybranymi liniami w sezonie 2008/2009 przeprowadzono 1-powtórzeniowe doświadczenie w Bąkowie. Na podstawie uzyskanych wyników do dalszych badań wybrano 18 linii o porównywalnym plonie do odmian wzorcowych i odpornych na mączniaka (tab. 1).

Tabela 1. Plon ziarna, zimotrwałość, odporność na mączniaka i wyleganie oraz wysokość roślin linii jęczmienia ozimego - Bąków, 2009

Table 1. Yield, winter hardiness, resistance to powdery mildew, lodging and plant height of selected lines of winter barley - Bąków, 2009

\begin{tabular}{|c|c|c|c|c|c|c|}
\hline $\begin{array}{l}\text { Lp. } \\
\text { No. }\end{array}$ & $\begin{array}{c}\text { Linia } \\
\text { Breeding line }\end{array}$ & $\begin{array}{l}\text { Plon } \\
\text { Yield } \\
\text { [dt/ha] }\end{array}$ & $\begin{array}{l}\text { Przezimowanie* } \\
\text { Winter hardiness }\end{array}$ & $\begin{array}{c}\text { Mączniak } \\
\text { prawdziwy } \\
\text { Powdery mildew }\end{array}$ & $\begin{array}{l}\text { Wyleganie } \\
\text { Lodging }\end{array}$ & $\begin{array}{l}\text { Wysokość } \\
\text { roślin } \\
\text { Plant height } \\
{[\mathrm{cm}]}\end{array}$ \\
\hline 1 & 2 & 3 & 4 & 5 & 6 & 7 \\
\hline 1 & BKH 458 & 73,2 & 9 & 8 & 9 & 84 \\
\hline 2 & BKH 1288 & 72,0 & 9 & 8 & 9 & 80 \\
\hline 3 & BKH 248 & 71,4 & 8 & 8 & 9 & 73 \\
\hline 4 & BKH 1127 & 70,3 & 9 & 7 & 9 & 81 \\
\hline 5 & BKH 1153 & 69,8 & 9 & 9 & 9 & 87 \\
\hline 6 & BKH 1366 & 69,5 & 9 & 8 & 9 & 81 \\
\hline 7 & BKH 549 & 69,1 & 9 & 8 & 9 & 63 \\
\hline 8 & BKH 1314 & 69,0 & 9 & 9 & 9 & 78 \\
\hline 9 & MAYBRIT & 68,4 & 9 & 5 & 9 & 88 \\
\hline 10 & BKH 727 & 67,6 & 9 & 7 & 9 & 79 \\
\hline 11 & BKH 403 & 67,0 & 9 & 6 & 9 & 81 \\
\hline 12 & BKH 859 & 66,8 & 8 & 9 & 9 & 68 \\
\hline 13 & BKH 763 & 66,7 & 9 & 7 & 9 & 75 \\
\hline 14 & ВКH 1469 & 66,6 & 9 & 4 & 9 & 57 \\
\hline 15 & BKH 695 & 66,4 & 9 & 7 & 9 & 78 \\
\hline 16 & BKH 333 & 66,3 & 9 & 8 & 9 & 74 \\
\hline 17 & BKH 5735 & 66,3 & 9 & 9 & 9 & 79 \\
\hline 18 & BKH 317 & 66,0 & 9 & 8 & 9 & 78 \\
\hline 19 & BKH 848 & 65,5 & 8 & 7 & 9 & 74 \\
\hline 20 & BKH 238 & 65,2 & 9 & 8 & 9 & 68 \\
\hline 21 & NICKELA & 64,1 & 8 & 8 & 9 & 65 \\
\hline 22 & BKH 620 & 63,3 & 9 & 4 & 9 & 67 \\
\hline 23 & BKH 1793 & 62,7 & 9 & 5 & 9 & 82 \\
\hline 24 & ВKH 661 & 61,7 & 9 & 8 & 9 & 63 \\
\hline 25 & В КН 359 & 61,3 & 8 & 9 & 9 & 75 \\
\hline 26 & BKH 744 & 60,9 & 9 & 8 & 9 & 80 \\
\hline 27 & BKH 813 & 60,9 & 8 & 8 & 9 & 86 \\
\hline 28 & BKH 806 & 60,5 & 9 & 8 & 9 & 87 \\
\hline 29 & BKH 1819 & 60,2 & 9 & 5 & 9 & 79 \\
\hline 30 & BKH 1826 & 60,1 & 9 & 3 & 9 & 83 \\
\hline
\end{tabular}




\begin{tabular}{|c|c|c|c|c|c|c|}
\hline 1 & 2 & 3 & 4 & 5 & 6 & 7 \\
\hline 31 & BKH 479 & 59,3 & 8 & 6 & 9 & 85 \\
\hline 32 & BKH 518 & 59,3 & 9 & 5 & 9 & 77 \\
\hline 33 & BKH 1200 & 59,0 & 9 & 8 & 9 & 80 \\
\hline 34 & BKH 553 & 58,7 & 8 & 7 & 9 & 64 \\
\hline 35 & BKH 754 & 58,1 & 9 & 6 & 9 & 80 \\
\hline 36 & BКH 794 & 57,9 & 9 & 5 & 9 & 76 \\
\hline 37 & BKH 293 & 57,4 & 9 & 7 & 9 & 99 \\
\hline 38 & BKH 273 & 57,1 & 9 & 6 & 9 & 74 \\
\hline 39 & BKH 6 & 57,0 & 8 & 7 & 9 & 82 \\
\hline 40 & BKH 1786 & 56,7 & 9 & 7 & 9 & 75 \\
\hline 41 & BKH 227 & 56,5 & 8 & 5 & 9 & 75 \\
\hline 42 & BKH 186 & 56,0 & 9 & 7 & 9 & 66 \\
\hline 43 & BKH 1235 & 55,8 & 9 & 6 & 9 & 87 \\
\hline 44 & BКH 789 & 55,4 & 9 & 7 & 9 & 74 \\
\hline 45 & BKH 78 & 55,3 & 8 & 9 & 9 & 73 \\
\hline 46 & BKH 14 & 54,8 & 8 & 6 & 9 & 69 \\
\hline 47 & BKH 220 & 54,6 & 9 & 7 & 9 & 71 \\
\hline 48 & BKH 83 & 54,4 & 8 & 6 & 9 & 74 \\
\hline 49 & BKH 1734 & 54,1 & 8 & 8 & 9 & 87 \\
\hline 50 & BKH 1414 & 54,0 & 9 & 7 & 9 & 81 \\
\hline 51 & ВКН 985 & 52,7 & 9 & 7 & 9 & 71 \\
\hline 52 & BKH 205 & 52,5 & 8 & 8 & 9 & 66 \\
\hline 53 & BKH 1484 & 52,0 & 8 & 8 & 9 & 70 \\
\hline 54 & BKH 773 & 51,7 & 8 & 6 & 9 & 75 \\
\hline 55 & BKH 105 & 51,2 & 9 & 6 & 9 & 64 \\
\hline 56 & ВКН 653 & 51,0 & 9 & 4 & 9 & 67 \\
\hline 57 & ВКН 976 & 49,8 & 9 & 8 & 9 & 69 \\
\hline 58 & BKH 39 & 4,94 & 9 & 6 & 9 & 77 \\
\hline 59 & BKH 1494 & 48,5 & 8 & 8 & 9 & 77 \\
\hline 60 & BKH 1503 & 45,7 & 9 & 8 & 9 & 80 \\
\hline 62 & BKH 1554 & 42,0 & 9 & 9 & 9 & 83 \\
\hline \multicolumn{2}{|c|}{$\begin{array}{l}\text { Średnia ogólna } \\
\text { Average overall }\end{array}$} & 59,9 & 8,7 & 7,0 & 9 & 76,1 \\
\hline \multicolumn{2}{|c|}{$\begin{array}{l}\text { Średnia wzorce } \\
\text { Average patterns }\end{array}$} & 63,4 & 7,9 & 4,7 & 9 & 83,7 \\
\hline \multicolumn{2}{|c|}{$\begin{array}{l}\text { Odchylenie standardowe wzorce } \\
\text { Standard deviation patterns }\end{array}$} & 2,1 & 0,1 & 0,6 & 0 & 1,2 \\
\hline
\end{tabular}

*W skali 1-9- using 1-9 scale

W roku 2010, 18 wybranych linii i 15 innych linii hodowlanych jęczmienia ozimego o symbolach: POA lub WTDL oceniono w trzech miejscowościach. W warunkach kontrolowanych oceniono $\mathrm{w}$ stadium siewki reakcję na zakażenie izolatem 63 B. graminis f. sp. hordei. Na podstawie uzyskanych wyników, można stwierdzić, że 10 linii BKH plonowało na poziomie plenniejszej odmiany wzorcowej Maybrit (tab. 2). W tabeli 3. przedstawiono wyniki oceny odporności 18 linii $\mathrm{BKH}$ na mączniaka w stadium siewki i warunkach polowych. Odporność linii: BKH 1153, BKH 1314, BKH 859 i BKH 5735 w warunkach naturalnej infekcji $\mathrm{w}$ doświadczeniu polowym była zgodna $\mathrm{z}$ oceną $\mathrm{w}$ stadium siewki w warunkach kontrolowanych. Pozostałe linie BKH zakażane izolatem 63 B. graminis f. sp. hordei były heterogeniczne - reakcja $0(4)$ i $4,0(4)$ i 2 , średnio odporne - reakcja 2 i podatne reakcja 4. Linie te $w$ warunkach polowych oceniono od średnio odpornych do podatnych. Biorąc pod uwagę homozygotyczną odporność linii BKH 5735 na porażenie przez B. graminis f. sp. hordei, udokumentowaną wynikami ocen w warunkach kontrolowanych, naturalnej infekcji (tab. 3) i oceny molekularnej oraz porównywalną ocenę innych cech wartości gospodarczej w porównaniu do odmian wzorcowych (tab. 2, 3, 4), linia BKH 5735 jest 
formą jęczmienia ozimego odporną na $B$. graminis f. sp. hordei uwarunkowaną genem mlo.

W Polsce patotypy wirulentne w stosunku do większości genów obecnych w odmianach jęczmienia jarego i ozimego zarejestrowanych przez COBORU występują z różnym nasileniem, za wyjątkiem genu mlo (Czembor

Tabela 2. Plony ziarna linii włączonych do badań w Szelejewie, Bąkowie i Wiatrowie w roku 2010 [dt/ha]

Table 2. Grain yield of breeding lines evaluated in Szelejewo, Bąków and Wiatrowo in 2010 [dt/ha]

\begin{tabular}{|c|c|c|c|c|c|c|}
\hline \multirow{2}{*}{$\begin{array}{l}\text { Lp. } \\
\text { No. }\end{array}$} & \multirow{2}{*}{$\begin{array}{c}\text { Linia } \\
\text { Breeding line }\end{array}$} & \multicolumn{3}{|c|}{ Miejscowości - Locations } & \multirow{2}{*}{$\begin{array}{l}\text { Średnia } \\
\text { Mean }\end{array}$} & \multirow{2}{*}{$\begin{array}{c}\% \text { wzorca } \\
\% \text { of standard }\end{array}$} \\
\hline & & Szelejewo & Bąków & Wiatrowo & & \\
\hline 1 & BKH 458 & 58,4 & 57,8 & 90,5 & 68,9 & 107,9 \\
\hline 2 & WTDL 224 & 57,5 & 54,2 & 87,6 & 66,4 & 104,1 \\
\hline 3 & MAYBRIT wz. & 62,3 & 58,2 & 78,2 & 66,3 & 103,7 \\
\hline 4 & BKH 5735 & 62,3 & 58,4 & 77,3 & 66,0 & 103,3 \\
\hline 5 & WTDL 242 & 54,0 & 56,7 & 84,2 & 65,0 & 101,7 \\
\hline 6 & BKH 859 & 55,3 & 57,0 & 82,5 & 64,9 & 101,6 \\
\hline 7 & NICKELA wz. & 54,3 & 60,7 & 78,9 & 64,6 & 101,2 \\
\hline 8 & BKH 1127 & 50,9 & 57,7 & 84,4 & 64,3 & 100,7 \\
\hline 9 & BKH 1288 & 55,8 & 57,3 & 77,5 & 63,5 & 99,5 \\
\hline 10 & POA8 11-10 & 57,4 & 56,3 & 75,4 & 63,0 & 98,7 \\
\hline 11 & POA 1287-16 & 55,6 & 52,8 & 80,1 & 62,9 & 98,4 \\
\hline 12 & BKH 248 & 56,3 & 54,7 & 77,2 & 56,3 & 98,2 \\
\hline 13 & POA 858 & 53,7 & 53,9 & 80,3 & 53,7 & 98,1 \\
\hline 14 & WTDL 455 & 53,7 & 53,9 & 80,3 & 62,6 & 98,1 \\
\hline 15 & BKH 727 & 53,1 & 51,1 & 80,2 & 61,5 & 96,2 \\
\hline 16 & BKH 549 & 53,1 & 51,1 & 80,2 & 61,5 & 96,2 \\
\hline 17 & ROSITA wz. & 55,9 & 50,6 & 75,7 & 60,7 & 95,1 \\
\hline 18 & WTDL 1412 & 51,6 & 53,1 & 74,0 & 59,6 & 93,3 \\
\hline 19 & BKH 333 & 48,7 & 52,8 & 75,3 & 58,9 & 92,3 \\
\hline 20 & BКH 848 & 50,5 & 59,2 & 67,0 & 58,9 & 92,2 \\
\hline 21 & BKH 1366 & 51,8 & 51,4 & 72,1 & 58,4 & 91,5 \\
\hline 22 & BKH 317 & 54,6 & 54,1 & 65,8 & 58,2 & 91,1 \\
\hline 23 & BKH 238 & 47,6 & 49,8 & 76,4 & 58,0 & 90,8 \\
\hline 24 & BKH 1153 & 50,0 & 53,3 & 67,8 & 57,0 & 89,3 \\
\hline 25 & POA 788-10 & 48,1 & 56,8 & 65,9 & 56,9 & 89,2 \\
\hline 26 & BKH 1314 & 48,7 & 52,6 & 69,5 & 56,9 & 89,2 \\
\hline 27 & POA 1365-17 & 50,5 & 49,5 & 70,0 & 56,7 & 88,7 \\
\hline 28 & WTDL 1491 & 56,0 & 45,1 & 67,6 & 56,3 & 88,1 \\
\hline 29 & WTDL 81 & 40,7 & 51,8 & 75,3 & 56,0 & 87,6 \\
\hline 30 & POA 804-10 & 42,6 & 53,1 & 71,6 & 55,7 & 87,3 \\
\hline 31 & BKH 695 & 49,9 & 51,3 & 65,9 & 55,7 & 87,2 \\
\hline 32 & WTDL 1363 & 46,3 & 50,4 & 65,2 & 54,0 & 84,5 \\
\hline 33 & POA 1313-16 & 42,7 & 54,3 & 64,2 & 53,7 & 84,1 \\
\hline 34 & POA 762-10 & 39,3 & 50,5 & 70,5 & 53,4 & 83,7 \\
\hline 35 & BKH 763 & 40,2 & 47,9 & 52,5 & 52,5 & 82,2 \\
\hline 36 & ВКН 661 & 67,7 & 46,6 & 67,7 & 51,2 & 80,2 \\
\hline \multicolumn{2}{|c|}{ Średnia - Mean } & 51,3 & 53,6 & 74,6 & 59,9 & - \\
\hline \multicolumn{2}{|c|}{$\begin{array}{l}\text { NIR }(0,05) \\
\operatorname{LSD}(0.05)\end{array}$} & 10,9 & 6,4 & 9,0 & 7,0 & - \\
\hline \multicolumn{2}{|c|}{$\begin{array}{l}\operatorname{NIRP}(0,05) \\
\operatorname{LSDP}(0.05)\end{array}$} & $21,3 \%$ & $11,9 \%$ & $12,0 \%$ & - & $11,6 \%$ \\
\hline
\end{tabular}


Tabela 3. Odporność linii wybranych do doświadczenia w 3 miejscowościach na mączniaka prawdziwego po zakażeniach izolatem 63 Blumeria graminis f. sp. hordei w warunkach kontrolowanych oraz w warunkach polowych

Table 3. Resistance level of breeding lines selected to the experiments for powdery mildew evaluation after inoculation by isolate 63 of Blumeria graminis f. sp. hordei under controlled conditions and conducted in three locations under field conditions

\begin{tabular}{|c|c|c|c|}
\hline \multirow[b]{2}{*}{$\begin{array}{l}\text { Lp. } \\
\text { No. }\end{array}$} & \multirow[b]{2}{*}{$\begin{array}{c}\text { Linia } \\
\text { Breeding line }\end{array}$} & \multicolumn{2}{|c|}{ Odporność - Resistance } \\
\hline & & $\begin{array}{l}\text { stadium siewki - izolat } 63 * \\
\text { growth stage of seedlings - } \\
\text { isolate } 63\end{array}$ & $\begin{array}{l}\text { polowa** } \\
\text { field resistance }\end{array}$ \\
\hline 1 & BKH 458 & 2 & 8 \\
\hline 2 & BKH 1288 & 2 & 8 \\
\hline 3 & BKH 248 & 2 i $0(4)$ & 8 \\
\hline 4 & BKH 1127 & 4 & 7 \\
\hline 5 & BKH 1153 & $0(4)$ & 9 \\
\hline 6 & BKH 1366 & $0(4)$ i 4 & 8 \\
\hline 7 & BKH 549 & 2 & 8 \\
\hline 8 & BKH 1314 & $0(4)$ & 9 \\
\hline 9 & BKH 727 & 4 & 7 \\
\hline 10 & BKH 403 & 4 & 6 \\
\hline 11 & BKH 859 & $0(4)$ & 9 \\
\hline 12 & BKH 763 & 4 & 7 \\
\hline 13 & BKH 1469 & 4 & 4 \\
\hline 14 & BKH 695 & 4 & 7 \\
\hline 15 & BKH 333 & 2 & 8 \\
\hline 16 & BKH 5735 & $0(4)$ & 9 \\
\hline 17 & BKH 317 & 2 & 8 \\
\hline 18 & BKH 848 & 2 & 7 \\
\hline \multicolumn{2}{|c|}{ MAYBRIT wz. } & 4 & 5 \\
\hline
\end{tabular}

*ocena w skali 1-4- using 1-4 scale

** ocena w skali 1-9 - using 1-9 scale

Tabela 4. Opis linii BKH 5735 jako źródła odporności typu Mlo jęczmienia ozimego

Table 4. Characteristics of the BKH 5735 line as a source of winter barley Mlo resistance

\begin{tabular}{|c|c|c|c|c|}
\hline \multirow{2}{*}{$\begin{array}{c}\text { Linia BKH } 5735 \\
\text { BKH } 5735 \text { line }\end{array}$} & \multirow{2}{*}{$\begin{array}{l}\text { Gen } \\
\text { Gene }\end{array}$} & \multicolumn{2}{|c|}{$\begin{array}{l}\text { Odporność na mączniaka } \\
\text { Powdery mildew resistance }\end{array}$} & \multirow{2}{*}{$\begin{array}{l}\text { Plon* } \\
\text { Yield }\end{array}$} \\
\hline & & $\begin{array}{l}\text { stadium siewki } \\
\text { growth stage of seedling }\end{array}$ & $\begin{array}{l}\text { polowa } \\
\text { field resistance }\end{array}$ & \\
\hline BKH 5735 forma ozima - winter & $m l o_{11}$ & $0(4)$ & 9 & 7 \\
\hline Rodzice - Parents & - & - & - & - \\
\hline Bażant forma ozima - winter & $\begin{array}{c}\text { heterogenny** } \\
\text { heterogenous }\end{array}$ & 4 & 5 & 7 \\
\hline Carola forma ozima - winter & $M l a_{6}{ }^{* *}$ & 4 & 7 & 8 \\
\hline Danuta forma jara - spring & $m l o_{11} * * *$ & $0(4)$ & 9 & 7 \\
\hline Pochodzenie - Pedgree & - & - & - & - \\
\hline$($ Carola $\times$ Danuta $) \times$ Bażant & - & - & - & - \\
\hline
\end{tabular}

Dostępny w Banku Genów IHAR - PIB w Radzikowie pod numerem : 50105

Seeds are available in Gene Bank IHAR - PIB Radzików under numer: 50105

*ocena plonu w skali 1-9, 1 - najniższa, 9 - najwyższa - using 1-9 scale

**Lista Opisowa Odmian Roślin Rolniczych COBORU 2004 - according to COBORU 2004

***Schwarzbach 2008

i Czembor 2001, 2004; Czembor 2003, 2004; Gacek i wsp. 2004). Przykładowo, zarówno w 1999 roku, jak i w 2001 roku wykazano brak w Polsce korespondujących wiru- lencji w stosunku do genów odporności Mlo, Mla23 i Mlp (Czembor i Czembor 2001, 2004). Biorąc to pod uwagę można stwierdzić, że należą one do najbardziej efektyw- 
nych genów odporności na terenie Polski. Należy zwrócić uwagę na fakt ciągłego braku wirulecji korespondującej do odporności Mlo, pomimo że odmiany z tą odpornością były uprawiane w tym okresie na poziomie około $17,6 \%$. Podobne wyniki uzyskano badając odmiany włączone do badań rejestrowych w Polsce w 2011 roku (Czembor i wsp. 2012). Bieżące badania mają charakter oryginalny, ponieważ wykazały na możliwość uzyskania genotypów jęczmienia ozimego o wysokiej odporności na mączniaka prawdziwego jęczmienia (B. graminis f. sp. hordei) warunkowanej efektywnym genem mlo przy równoczesnym zachowaniu wysokiej wartości agronomicznej.

\section{Wnioski / Conclusions}

1. Gen mlo może zostać włączony do programów hodowlanych, których celem jest uzyskanie odmian jęczmienia ozimego o wysokiej odporności na mączniaka prawdziwego (B. graminis f. sp. hordei) nie wpływając przy tym negatywnie na ich wartość agronomiczną.

2. Linia jęczmienia ozimego BKH 5735 stanowi cenne źródło odporności na mączniaka prawdziwego typu Mlo.

Praca finansowana $\mathrm{z}$ programu Postępu Biologicznego Ministerstwa Rolnictwa i Rozwoju Wsi, zadanie 39.

\section{Literatura / References}

Anonymous. 2004. Lista opisowa odmian. Cz. 1. Zbożowe. COBORU, Słupia Wielka: 57-65.

Bjørnstad A., Aastveit K. 1990. Pleiotropic effects on the $m l-o$ mildew resistance gene in barley in different genetical backgrounds. Euphytica 46 (3): 217-226.

Czembor J.H. 2002. Resistance to powdery mildew in selections from Moroccan barley landraces. Euphytica 125 (3): $397-409$.

Czembor H.J. 2003. Odporność krajowych odmian jęczmienia jarego na mączniaka prawdziwego (Blumeria graminis f. sp. hordei). Biuletyn Instytutu Hodowli i Aklimatyzacji Roślin 230: 327-334.

Czembor H.J. 2004. Odporność krajowych odmian jęczmienia ozimego na mączniaka prawdziwego (Blumeria graminis f. sp. hordei). Biuletyn Instytutu Hodowli i Aklimatyzacji Roślin 233: 117-125.

Czembor J.H., Czembor H.J. 1998. Powdery mildew resistance in cultivars of spring barley from Polish register. Plant Breeding and Seed Science 42 (2): 87-99.

Czembor J.H., Czembor H.J. 1999. Powdery mildew resistance in cultivars of winter barley from Polish register. Plant Breeding and Seed Science 43 (1): 65-75.

Czembor H.J., Czembor J.H. 2001. Resistance to powdery mildew in barley cultivars and breeding lines included in 1998-2000 Polish registration trials. Plant Breeding and Seed Science 45 (1): 21-41.

Czembor J.H., Czembor E. 2003. Odporność Mlo jęczmienia na mączniaka prawdziwego (Blumeria graminis f. sp. hordei). Cz. III. Trwałość odporności. Biuletyn Instytutu Hodowli i Aklimatyzacji Roślin 230: 375-386.

Czembor J.H., Czembor H.J. 2004a. Chorobotwórczość mączniaka prawdziwego jęczmienia (Blumeria graminis f. sp. hordei) w Polsce w roku 1999. Biuletyn Instytutu Hodowli i Aklimatyzacji Roślin 231: 377-386.

Czembor H.J., Czembor J.H. 2004b. Chorobotwórczość mączniaka prawdziwego jęczmienia (Blumeria graminis f. sp. hordei) w Polsce w roku 2000. Biuletyn Instytutu Hodowli i Aklimatyzacji Roślin 233: 107-115.

Czembor J.H., Czembor H.J. 2005. Chorobotwórczość mączniaka prawdziwego jęczmienia (Blumeria graminis f. sp. hordei) w Polsce w roku 2001. Biuletyn Instytutu Hodowli i Aklimatyzacji Roślin 236: 183-192.

Czembor H.J., Czembor J.H., Pietrusińska A., Domeradzka O. 2012. Odporność na mączniaka prawdziwego (Blumeria graminis f. sp. hordei) odmian jęczmienia włączonych do badań rejestrowych w Polsce w roku 2011. Biuletyn Instytutu Hodowli i Aklimatyzacji Roślin 265: 23-33.

Czembor J.H., Doraczyńska O., Pietrusińska A., Czembor H.J. 2013. Odporność na mączniaka prawdziwego (Blumeria graminis f. sp. hordei) odmian jęczmienia włączonych do badań rejestrowych w Polsce w roku 2012. Biuletyn Instytutu Hodowli i Aklimatyzacji Roślin 268: 35-45.

Czembor H.J., Gacek E. 1990. Wybrane problemy hodowli odpornościowej zbóż na choroby. Biuletyn Instytutu Hodowli i Aklimatyzacji Roślin 173-174: 53-64.

Dreiseitl A. 1991a. Analysis of powdery mildew (Erysiphe graminis f. sp. hordei) populations. Genetika a Šlechtění 27: 39-46.

Dreiseitl A. 1991b. A Czechoslovak test-assortment of spring barley cultivars for identifying powdery mildew pathotypes. Genetika a Šlechtění 27: 251-257.

Dreiseitl A. 1997. Changes in the barley powdery mildew population in the Czech Republic (1993-1994). Ochrana Rostlin 33: $281-296$.

Dreiseitl A. 1998. Comparison of methods to study powdery mildew and monitor the population of Erysiphe graminis f. sp. hordei in 1997. Plant Protection Science 34: 33-38.

Dreiseitl A. 2004. Virulence frequencies to powdery mildew resistance genes of winter barley cultivars. Plant Protection Science 40 (4): $135-140$.

Dreiseitl A. 2008. Virulence frequency to powdery mildew resistances in winter barley cultivars. Czech Journal of Genetics and Plant Breeding 44 (4): 160-166.

Dreiseitl A. 2011a. Differences in powdery mildew epidemics in spring and winter barley based on 30-year variety trials. Annals of Applied Biology 159 (1): 49-57.

Dreiseitl A. 2011b. Resistance of 'Roxana' to powdery mildew and its presence in some European spring barley cultivars. Plant Breeding 130: 419-422.

Dreiseitl A. 2011c. Resistance of 'Laverda' to powdery mildew and its presence in some winter barley cultivars. Cereal Research Communications 39 (4): 569-576.

Dreiseitl A. 2011d. Changes in the population of Blumeria graminis f. sp. hordei in the Czech Republic from 2009 to 2010. Plant Protection Science 47: 43-51. 
Dreiseitl A. 2012. Frequency of powdery mildew resistances in spring barley cultivars evaluated in Czech variety trials. Plant Protection Science 48 (1): 17-20.

Dreiseitl A. 2013. Genes for resistance to powdery mildew in European winter barley cultivars registered in the Czech Republic and Slovakia to 2010. Plant Breeding 132 (6): 558-562.

Dreiseitl A. 2014a. Pathogenic divergence of Central European and Australian populations of Blumeria graminis f. sp. hordei. Annals of Applied Biology 165: 364-372.

Dreiseitl A. 2014b. The Hordeum vulgare subsp. spontaneum - Blumeria graminis f. sp. hordei pathosystem: its position in resistance research and breeding applications. European Journal of Plant Pathology 138: 561-568.

Dreiseitl A., Kosman E. 2013. Virulence phenotypes of Blumeria graminis f. sp. hordei in South Africa. European Journal of Plant Pathology 136 (1): 113-121.

Dreiseitl A., Platz G. 2012. Powdery mildew resistance genes in barley varieties grown in Australia. Crop \& Pasture Science 63: 997-1006.

Dreiseitl A., Schwarzbach E. 1994. Composition of the powdery mildew population on barley in Central Moravia (Czech Republic) in 1992. Rostlinná Výroba 40: 545-554.

Gacek E. 1990. Studia nad sposobami wykorzystania odporności genetycznej jęczmienia w zwalczaniu mączniaka prawdziwego (Erysiphe graminis DC f. sp. hordei Marchal). Hodowla Roślin, Aklimatyzacja i Nasiennictwo 34 (5/6): 3-48.

Gacek E., Biliński Z.R., Czembor H.J., Czembor J.H. 2004. Chorobotwórczość mączniaka prawdziwego jęczmienia (Blumeria graminis f. sp. hordei) w Polsce w latach 1993-1996. Biuletyn Instytutu Hodowli i Aklimatyzacji Roślin 231: 365-376.

Gacek E., Czembor H.J., Nadziak J. 1996. Wpływ zróżnicowania genetycznego w mieszaninach i mieszankach zbożowych na rozwój chorób i plonowanie. Biuletyn Instytutu Hodowli i Aklimatyzacji Roślin 200: 203-209.

Higgins C.M., Hall R.M., Campbell P.R., Dietzgen R.G. 2000. PCR rescue and analysis of transgene sequences directly from crude extracts of transgenic embryos and plants. Plant Molecular Biology Reporter 18: 285a-285g.

Hovmøller M.S., Caffier V., Jalli M., Andersen O., Besenhofer G., Czembor J.H., Dreiseitel A., Flath K., Fleck A., Heinrics F., Jonsson R., Limpert E., Mercer P., Plesnik S., Rashal I., Skinnes H., Slater S., Vronska O. 2000. The European barley powdery mildew virulence survey and disease nursery1993-1999. Agronomie 20 (7): 729-744.

Karakousis A., Barr A.R., Chalmers K.J., Ablett G.A., Holton T.A., Henry R.J., Lim P., Langridge P. 2003. Potential of SSR markers for plant breeding and variety identification in Australian barley germplasm. Australian Journal of Agricultural Research 54 (11-12): 1197-1210.

Kozdój J., Mańkowski D., Czembor H.J. 2009. Analiza plonu jęczmienia jarego (Hordeum vulgare L.) porażonego mączniakiem prawdziwym (Blumeria graminis f. sp. hordei). Komunikat. Biuletyn Instytutu Hodowli i Aklimatyzacji Roślin 254: 65-74.

Limpert E., Godet F., Müller K. 1999. Dispersal of cereal mildews across Europe. Agricultural and Forest Meteorology 97 (4): $293-308$.

Nieróbca A., Horoszkiewicz-Janka J., Czembor J.H. 2003. Ochrona roślin - ważny element technologii uprawy zbóż w UE. Pamiętnik Puławski 132: 311-320.

Pecio A., Bichoński A. 2003. Plon i jakość browarna ziarna jęczmienia jarego w zależności od sposobu ochrony roślin przed chorobami. Biuletyn Instytutu Hodowli i Aklimatyzacji Roślin 230: 317-326.

Ramsay L., Macauly M., McLean K., Fuller J., Edwards K., Turesson S., Morgante M., Idegli-Ivanissivich S., Marmiroli N., Maestri E., Massari A., Powell W., Waugh R. 2000. A simple sequence repeat-based linkage map on barley. Genetics 156 (4): $1997-2005$.

Rasmusson D.C. (ed.). 1985. Barley. Agronomy Series No. 26. American Society of Agronomy, Crop Science Society of America, Soil Science Society of America, Publishers, Madison, Wisconsin, USA.

Schwarzbach E. 2008. WORK-index mlo. http://www.crpmb.org/mlo/ [Accessed: 20.05.2016].

Szarzyńska J. 2015. Jęczmień. s. 22-45. W: „Lista opisowa odmian roślin rolniczych“ (E. Gacek, red.). COBORU, Słupia Wielka, 188 ss. 